Témoigner Témoigner. Entre histoire et mémoire

Getuigen Revue pluridisciplinaire de la Fondation Auschwitz

$116 \mid 2013$

Voyages mémoriels

\title{
La gloire et la culture, à propos de l'élection de « Miss Holocaust »
}

Glory and culture, on the election of "Miss Holocaust"

Glorie en cultuur: de verkiezing van 'Miss Holocaust'

\section{Philippe Mesnard}

\section{(2) OpenEdition}

Journals

\section{Édition électronique}

URL : http://journals.openedition.org/temoigner/646

DOI : 10.4000/temoigner.646

ISSN : 2506-6390

Éditeur :

Éditions du Centre d'études et de documentation Mémoire d'Auschwitz, Éditions Kimé

Édition imprimée

Date de publication : 1 septembre 2013

Pagination : 6

ISBN : 978-2-84174-643-9

ISSN : 2031-4183

\section{Référence électronique}

Philippe Mesnard, « La gloire et la culture, à propos de l'élection de « Miss Holocaust » », Témoigner. Entre histoire et mémoire [En ligne], 116 | 2013, mis en ligne le 01 juin 2015, consulté le 23 octobre 2020. URL : http://journals.openedition.org/temoigner/646 ; DOI : https://doi.org/10.4000/temoigner. 646 


\section{La gloire et la culture, à propos de l'élection de « Miss Holocaust »}

Le 23 août dernier, le quotidien israélien Haaretz publie un article de Marysa FoxBevilacqua au titre provoquant : « Miss Holocaust, the most unorthodox pageant of all », avec pour sous-titre : Survivors hit the runway for the second year of the controversial competition, and show the world a new face of survival. Le concours a eu lieu à Haifa devant de nombreux spectateurs (ou badauds). Trois cents femmes juives ayant survécu aux camps se seraient présentées, l'une d'entre elles (son nom est mentionné dans l'article) de 93 ans aurait été lauréate. Je ne m’attarderai pas sur les détails fournis dans l'article, ni sur ceux repris et mis en exergue par l'article du Monde qui répercute l' «événement ».

Évidemment, les réactions ne se sont pas fait attendre. On peut trouver que c'est exagéré, très exagéré, voire que c'est « une honte ». Être choqué. On peut aussi en rire et dire que c'est une revanche. Il y en a bien sûr qui se saisissent des faits comme d'un prétexte pour laisser s'exprimer, toujours sous le masque de la fameuse indignation, leur antisémitisme. D’autres encore dénoncent la glamourisation de cette collusion entre pop culture et mémoire de la Shoah.

Le grotesque, la farce, le « mauvais goût » ont toujours été des registres du comique permettant périodiquement de représenter la Shoah - en choquant. Peut-être cette manifestation est-elle une expression du genre?

Il y a un double phénomène qui est le propre de la dialectique culturelle: le mouvement et, pour ainsi dire, l'existence même de la culture consiste à s'approprier ce qui lui échappe et la violence génocidaire est précisément ce qui s'y soustrait le plus radicalement, son Dehors radical, c'est pourquoi la culture n'en a jamais fini de chercher à se l'approprier'. L'unorthodox pageant est - au-delà des motivations de ses acteurs - un symptôme de cet état de la culture.

Mais il ne s'agit pas seulement là de la culture en général, dans son sens anthropologique. Rapprochons le plan, resserrons la focale, chaque culture nationale (locale et non globale, communautaire et non universelle) a ses spécificités. La culture israélienne a les siennes, très singulières et parfois déstabilisantes, et pour bien comprendre cet événement il faut alors le resituer dans un contexte où, très tôt, à partir des années 1950, le génocide s'est trouvé représenté de façon extrêmement provocatrice, notamment au théâtre devenu, en l'occurrence, une scène privilégiée.

Précisément, le concours Miss Holocaust ne s'est-il pas déroulé sur une scène ? Ne devons-nous pas voir ce spectacle comme une Performance qui tente de transformer le traumatisme en gloire culturelle?

Philippe Mesnard, Rédacteur en chef

(1) Au risque de se perdre 